\title{
COMPILATION OF REGIONAL TO GLOBAL INVENTORIES OF ANTHROPOGENIC EMISSIONS
}

\author{
Carmen M. Benkovitz \\ Atmospheric Sciences Division \\ Environmental Sciences Department \\ Brookhaven National Laboratory \\ Upton, NY 11973
}

November 2001

Submitted for publication in

"Emissions of Chemical Species and Aerosols into the Atmosphere", Precursors of Ozone and their Effects in the Troposphere (POET), Kluwer Academic Publishers, Dordrecht, Netherlands.

By acceptance of this article, the publisher and/or recipient acknowledges the U.S. Government's right to retain a nonexclusive, royalty-free license in and to any copyright covering this paper.

Research by BNL investigators was performed under the auspices of the U.S. Department of Energy under Contract No. DE-AC02-98CH10886. 


\title{
Compilation of Regional to Global Inventories of Anthropogenic Emissions
}

\author{
Carmen M. Benkovitz \\ Atmospheric Sciences Division \\ Environmental Sciences Department \\ Brookhaven National Laboratory \\ Upton, NY 11973 \\ USA
}

\begin{abstract}
The mathematical modeling of the transport and transformation of trace species in the atmosphere is one of the scientific tools currently used to assess atmospheric chemistry, air quality, and climatic conditions. From the scientific but also from the management perspectives accurate inventories of emissions of the trace species at the appropriate spatial, temporal, and species resolution are required. There are two general methodologies used to estimate regional to global emissions: bottom-up and top-down (also known as inverse modeling). Bottom-up methodologies to estimate industrial emissions are based on activity data, emission factors (amount of emissions per unit activity), and for some inventories additional parameters (such as sulfur content of fuels). Generally these emissions estimates must be given finer sectoral, spatial (usually gridded), temporal, and for some inventories species resolution. Temporal and spatial resolution are obtained via the use of surrogate information, such as population, land use, traffic counts, etc. which already exists in or can directly be converted to gridded form. Speciation factors have been and are being developed to speciate inventories of $\mathrm{NO}_{\mathrm{x}}$, particulate matter, and hydrocarbons. Top-down (inverse modeling) methodologies directly invert air quality measurements in terms of poorly known but critical parameters to constrain the emissions needed to explain these measurements; values of these parameters are usually computed using atmospheric transport models. Currently there are several strong limitations of inverse modeling, but the continued evolution of top-down estimates will be facilitated by the development of denser monitoring networks and by the massive amounts of data from satellite observations.
\end{abstract}

\section{INTRODUCTION}

The mathematical modeling of the transport and transformation of trace species in the atmosphere is one of the scientific tools currently used to assess atmospheric chemistry, air quality, and climatic conditions. One of the most important inputs to such models is accurate inventories of emissions of the trace species included in the study at the appropriate sectoral, spatial, temporal and species resolution. In addition, from the management perspective emissions data are also required at these finer resolutions.

Emissions inventory compilation for scientific use started in the 1970s for oxides of sulfur and nitrogen. These initial inventories calculated global emissions by large geographic areas [Várhelyi, 1985], with very little spatial and temporal resolution. In the last three decades a wealth of information has been developed on anthropogenic activities and their emissions; however, these statistics must be used wisely to provide a true picture of the desired quantities. 
The following sections present an overall description of the current methodologies used to compile global to regional inventories of anthropogenic emissions. This discussion is by no means exhaustive; rather it attempts to give the reader an overview of how emissions from anthropogenic sources were and are being compiled [Baldasano and Power, 1998]. The methodologies described here can also be applied to the estimation of emissions from biogenic sources. For these sources the bottom-up approach is generally a more complicated model that may include parameters such as the meteorological conditions; whereas the top-down methodologies are usually directly applicable.

\section{INVENTORY DEVELOPMENT}

There are two general methodologies used to estimate regional to global emissions: bottom-up and top-down. Bottom-up methodologies apply the following general equation to estimate emissions:

$$
E_{i} A_{i}(E F)_{i} P_{1 i} P_{2 i} \ldots
$$

where $E_{i}$ are emissions and $A_{i}$ is the activity rate for a source (or group of sources), $(E F)_{i}$ is the emission factor (amount of emissions per unit activity), and $P_{1 i}, P_{2 i} \ldots$ are parameters that apply to the specified source types and species in the inventories (for example, sulfur content of the fuel, efficiency of the control technology). Top-down methodologies, also known as inverse modeling, derive emissions estimates by inverting measurements in combination with additional information such as the results of atmospheric transport and transformation models.

\section{USE OF BOTTOM-UP METHODOLOGIES TO ESTIMATE EMISSIONS}

The two major inputs needed to apply this methodology are the activity rates and the emission factors. To estimate the emissions of certain trace species additional parameters are needed; for example, to estimate sulfur emissions from fossil fuel combustion the sulfur content of the fuels is needed, for certain sources with emissions control devices the efficiency of these devices is needed.

Researchers compiling national inventories for their own country usually have access to information that may not be available to others; they also have more detailed knowledge of the types of processes and operating conditions which allows the use of nation-specific emission factors or adjustment of literature values. Generally these inventories estimate yearly emissions at the national, or for very large countries, at geographic subdivisions (states, provinces, etc.) level.

Researchers compiling regional or global inventories can either a) gather the national emissions estimates in the region of interest or b) estimate emissions directly using published information. To compile inventories by bringing together national estimates the information received must be checked for: a) completeness, b) transparency, c) consistency, d) comparability, and e) accuracy [Tarrasón and Schaug, 1999]. Examples of programs that rely on national submissions to build regional or global inventories include the Co-operative Programme for Monitoring and Evaluation of the Long Range Transmission of Air Pollutants in Europe (EMEP) and the 
Intergovernmental Panel for Climate Change (IPCC) [Houghton et al., 1997; Moran and Salt, 1996]. Collaborations have been set up between groups concerned with gathering emissions information such as EMEP, the United Nations Economic Commission for Europe (UNECE) [United Nations Economic Commission for Europe, 1997], the United Nations Framework Convention on Climate Change (UNFCCC) [United Nations Framework Convention on Climate Change, 2000] and unified reporting requirements have been developed to minimize the work of the national participants and to have a consistent set of emissions data available for the work of these groups [Houghton et al., 1997; Moran and Salt, 1996]. Step-by-step guidelines and workbooks have also been developed to help in the compilation of the needed data.

In June 1985 the European Council of Ministers defined a program for gathering, coordinating, and ensuring consistency of information on the state of the environment and natural resources in the European Community. This program was called CORINE (COoRdination d'INformation Environnementale), and one of its component projects is CORINAIR (CORINe AIR emissions inventory). This program is now run by the European Environment Agency (EEA). A prototype inventory was developed for 1985, CORINAIR85, which included a new nomenclature for source types, classification of emissions as large point sources and area sources, and especially developed software for data input and the calculation of emissions [Bouscaren, 1990; Bouscaren and Fontelle, 1992; Bouscaren, 1995; Bouscaren and Cornaert, 1995; Bouscaren et al., 1995]. Based on the experience gained in compiling CORINAIR85 and in collaboration with UNECE and with OECD the next phase of the project, CORINAIR90, has been defined [Bouscaren, 1992]. The goal of CORINAIR90 is to provide a complete, consistent, and transparent air pollutant emission inventory for Europe in 1990. New source sector splits have been defined (SNAP90), the list of pollutants and large point sources to be included have been expanded, and the availability of the CORINAIR software system has been extended to 30 countries.

In the work of the Global Emissions Inventory Activity (GEIA) group of the International Global Atmospheric Chemistry (IGAC) addressing emissions of $\mathrm{SO}_{2}$ and $\mathrm{NO}_{\mathrm{x}}$ from anthropogenic sources a "hybrid technique" is used. First a "default" global inventory is selected which includes emissions estimates derived using a unified methodology; then national or regional emissions estimates received from cooperating researchers are studied and if appropriate their data are substituted for those in the default inventory [Benkovitz et al., 1996]. An in depth study of all the data is done and differences and caveats are included in the accompanying documentation. Figure 1 presents a summary of the data used to develop the GEIA $\mathrm{SO}_{2}$ and $\mathrm{NO}_{\mathrm{x}}$ inventories for ca. 1985.

To directly estimate regional or global industrial emissions published information on activity rates, emission factors, and other pertinent parameters is needed. Examples of inventories compiled using this approach include the Emission Database for Global Atmospheric Research (EDGAR) [Olivier et al., 1999], a set of global emissions inventories of greenhouse gases and ozone-depleting substances for all anthropogenic and most natural sources on a per country basis (http://www.rivm.nl/index_en.html), the Regional Air Pollution Information and Simulation Model (RAINS) Asia [Arndt et al., 1997], a set of $\mathrm{SO}_{2}$ emissions data for Asia [Foell et al., 1995], and the global $\mathrm{CO}_{2}$ emissions compiled by Marland et al. [Marland et al., 1994]. In 
general, the activity rates are derived from data compiled by "multi-national" organizations. The two major sources of statistics on energy production, trade, and use are the United Nations (UN) [United Nations, 1988; United Nations, 1989] and the International Energy Agency (IEA) [International Energy Agency, 2000]. Other sources of activity data for specific sectors include but are not limited to the World Energy Council [World Energy Council, 1998], British Petroleum, the World Resources Institute [World Resources Institute, 2000], the World Bank [The World Bank Group, 2000], the International Monetary Fund [International Monetary Fund Staff, 2000], the Food and Agriculture Organization (FAO) of the United Nations [Food and Agriculture Organization of the United Nations, 2000] and the Vehicle Manufacturers Association of the United States [Motor Vehicle Manufacturers Association of the United States, 1998]. These compilations are usually not independent data sets because they are based on some of the same sources for national data; the published numbers are the result of slightly different questionnaires and different analysis by the respective offices and are also reported for somewhat different categories. When using any of these sources of activity rates the data must be carefully checked for completeness and homogeneity to avoid either double counting or dropping emissions.

The U.S. Environmental Protection Agency has developed and maintains a compilation of emission factors applicable to U.S. sources [U.S. Environmental Protection Agency, 1999]. Canada has also developed methodologies applicable to their sources [Johnson et al., 1991]. The IPCC has developed extensive guidelines which include step by step methodologies and emission factors to be used in estimating and reporting emissions [Houghton et al., 1997]. In addition, some investigators either adapt the US or Canadian emission factors or perform literature searches for more appropriate values or for experimental data from which to develop their estimates; for examples see Kato and Akimoto [1992] and Arndt et al. [1997].

A vivid example of the impact that small differences in input data can have on emissions estimates is given by Marland et al. [1999] where the annual by country $\mathrm{CO}_{2}$ emissions values in the Marland et al. inventory were compared with those in the EDGAR inventory. Marland et al. rely mainly on statistics gathered by the UN while EDGAR relies mainly on statistics gathered by the IEA supplemented by UN statistics when needed. After trying to account for the different sectors and emission factors included in each inventory results show that most of the emissions estimates cluster around the 1:1 line. The mean of all country differences between the two inventories is about $1 \%$, but the fractional differences tend to be larger for countries with smaller emissions, probably due to larger uncertainties in the activity rate information. However, the relative difference between the two estimates for US emissions is only $0.9 \%$, but the absolute difference is larger than the total emissions from 147 of the 195 countries included in the analysis. For the former USSR the relative difference is about $8.1 \%$, but the absolute difference exceeds the total emissions from all but the 14 largest emitting countries.

Direct measurements of emissions can be carried out using continuous emissions monitoring (CEM) techniques; this methodology produces the most accurate emissions estimates for the source/s being monitored at the temporal resolution of the measurements. In the United States these measurements are currently in use mainly at large stationary sources which are under strict 
guidelines for emissions control, such as power plants operating under State Implementation Plans.

\section{Sectoral, Temporal, Spatial, and Species Resolution}

For scientific studies and increasingly for management perspective emission inventories are needed by source sector at more detailed temporal, spatial, and species resolution. Because the main driving force for the compilation of national inventories is the need to regulate sources, emissions by source sectors are usually available in these inventories. Usually activity rate compilations are also developed by source sector. Unfortunately, the sectoral definitions are far from uniform; they vary from the very detailed descriptions used by the US Environmental Protection Agency (Source Classification Codes), the Canadian adaptation of this classification scheme, and CORINAIR SNAP90 to those with only a very limited number or no sectors. The EDGAR inventory and the $1990 \mathrm{SO}_{2}$ and $\mathrm{NO}_{\mathrm{x}}$ inventories of anthropogenic emissions developed at the Canadian Global Interpretation Centre (CGEIC) [Van Heyst et al., 1999] have adopted sector classifications that address the needs of regional to global studies. As an example, Table 1 presents the source classification used by the CGEIC inventories.

Except for CEM measured emissions there is a lack of information on emissions at finer temporal, spatial, and species resolutions; therefore surrogate methods are used to bring the inventory information to the desired resolutions.

The exact location (longitude, latitude) for most of the large stationary point sources such as power plants, smelters, etc. is currently available; this allows precise geographic assignment of their emissions. However, additional information needed to properly assign these emissions in the vertical, such as stack height, flow rate, temperature, etc. is rarely available. This additional information becomes critical to models where a more exact representation of plume dispersion is needed such as the plume-in-grid (PinG) section of the Community Multiscale Air Quality Modeling System [Byun and Ching, 1999]. The minimum information needed to estimate the vertical release height of large stationary point source emissions is the stack height; however, with only this information accurate plume dispersion cannot be represented.

The inventories compiled for the National Acid Precipitation Program (NAPAP) were among the first to address the conversion of emissions data to the finer spatial, temporal, and species resolution required by transport and transformation models [Saeger et al., 1989; Wagner et al., 1986]. This work developed temporal, spatial, and species allocation factors for emissions in the United States and Canada. Temporal allocation factors were based on surrogate information such as average heating degree days, continuous traffic counts from the U.S. Department of Transportation, operating schedules for power plants, etc. Twelve temporal categories were achieved: weekday, Saturday, and Sunday for each of the four seasons. The location of all major stationary sources was known, so the emissions were assigned to the corresponding grid cell. The spatial allocation factors for non-stationary sources were developed using the appropriate gridded surrogate information such as population, housing, land use types, etc. Speciation factors for $\mathrm{NO}_{x}$ used were those recommended in AP-42 [U.S. Environmental Protection Agency, 1985]; speciation factors for total suspended particulates (TSP), and total hydrocarbons (THC) 
were based on the Air Emissions Species Manual [Shareef and Bravo, 1993a; Shareef and Bravo, 1993b] developed for the U.S. Environmental Protection Agency.

The Generation of European Emissions Data (GENEMIS) project, a component of the European Experiment on Transport and Transformation of Environmentally Relevant Trace Constituents in the Troposphere over Europe (EUROTRAC) project, has developed values for European emissions at the appropriate temporal and spatial resolution for use in the EUROTRAC transport and transformation models [Hahn, 1996]. Starting with annual values temporal resolution of $1 / 2$ to one hour and daily and grid sizes of $80 \times 80$ and $60 \times 60$ are being achieved. The temporal disaggregation of annual emissions was accomplished by developing surrogate data at monthly, daily, and hourly resolutions for sources contributing the major part of the emissions in Europe [Lenhart and Friedrich, 1995]. The surrogate data include fuel use, working time, degree days, temperature, traffic counts, etc. Regression analysis using some of the surrogate data, qualitative expert judgements, plausibility tests, and some limited comparison between measurements and calculations have been used to determine the improvement of the temporal resolution of emissions calculated by these methods. In their study Lenhart and Friedich [1995] report that the differences between higher resolution emissions estimated by previously used methods and those estimated using GENEMIS methods range from $600 \%$ for public power plants to $30 \%$ for industrial combustion.

Some of the surrogate data needed to give emissions inventories finer resolution are not developed on a gridded basis; for example, population data are based on geopolitical division, transportation data are "line" sources, etc. For other data sets, such as satellite information, the "native" grid of the data may not exactly match that of the atmospheric models. The conversion of these data to gridded format (or regridding to a new grid definition) adds another source of uncertainty to the emissions data, so care must be exercised when developing and applying the gridded surrogate data. For example, in his work with the 1990 population counts Li [1996] had to take into consideration problems with multiple geographic entities (including ocean areas) within one grid cell and how this affects the distribution of both the population and ultimately the emissions.

\section{USE OF TOP-DOWN METHODOLOGIES TO ESTIMATE EMISSIONS}

Top-down, or inverse modeling, directly inverts air quality measurements in terms of poorly known but critical parameters [Heimann and Kasibhatla, 2000] to constrain the emissions needed to explain these measurements. The general format of a model representing a measurement $\left(y^{o}\right)$ is [Verstraete and Pinty, 2000]:

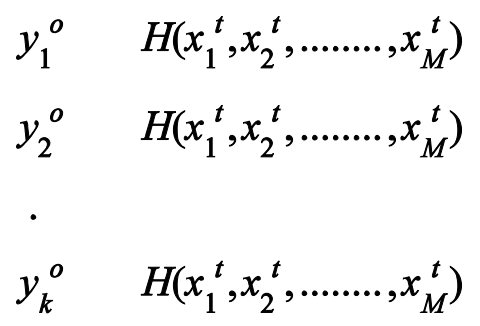


where $x_{m}^{t}, 1 \leq \mathrm{m} \leq \mathrm{M}$ are the state variables of the system, that is the smallest set of independent variables necessary to describe the measurements; values of the state variables are usually computed using atmospheric transport models. If $\mathrm{K}<\mathrm{M}$ the system is underdetermined, if $\mathrm{K}=\mathrm{M}$ a unique solution may be found but can be greatly affected by measurement errors, and if $\mathrm{K}>\mathrm{M}$ the system is overdetermined. Several statistical tools are being used to address the inversion problem, including empirical Bayes framework [Berger, 1985], synthesis inversion techniques based on Green's function [Enting, 2000], single value decomposition [Baker, 2000], and tangent linear and adjoint models [Giering, 2000].

Currently there are several strong limitations to this approach [Heimann and Kasibhatla, 2000]. It is harder to address emissions by sector using inverse modeling; Bergamaschi et al. [2000a] used individual model runs for each source category addressed, Houweling and van der Gon [1997] assumed that the dominant source of methane in Southeast Asia are rice paddies. For the long-lived atmospheric trace gases the signature in the measurements induced by various sources is small, so high precision measurements are needed. Emissions are highly variable so their representation needs many degrees of freedom making the inverse problem highly underdetermined. Emissions estimates are very sensitive to errors in the transport model [Houweling et al., 1999; Houweling et al., 2000]. The high diffusivity of atmospheric transport and mixing erase the small-scale emissions structure so that measurements at remote monitoring stations only capture the large-scale variability of the emissions. Additional a priori information based on model results, secondary observations or simplifications of the requirements for the inverse solution are needed, which introduces additional errors in the calculations. Thus the "skill" of inverse modeling is the judicious selection of the correct a priori information and the knowledge of the errors of such information.

Inverse modeling has been and is being used to study EMEP sulfur emissions estimates in Europe based on measurements from the EMEP monitoring network [Høst, 1996; Høst and Dimakos, 1997; Seibert, 1999], in oceanographic studies [Winguth et al., 2000], in studies of the fluxes of $\mathrm{CO}_{2}$ [Kaminski et al., 1999a; Kaminski et al., 1999b; Taguchi, 2000], CO [Bergamaschi et al., 2000b], and methane [Hein et al., 1997; Janssen et al., 1999; Vermeulen et al., 2000], in studies of the global methane cycle [Heimann and Kasibhatla, 2000; Hein et al., 1997; Houweling et al., 2000], and in studies of satellite data [Franssens et al., 2000]. This list of applications is by no means exhaustive; the evolution of inverse modeling will be facilitated by the development of denser monitoring networks and the massive amounts of data that are becoming available from satellite observations.

\section{FUTURE WORK}

The importance of having accurate estimates of emissions to the atmosphere of trace species is becoming more and more critical in the development of our basic scientific knowledge and to better control these emissions to mitigate detrimental effects such as adverse effects on human health, acid rain, and climate change. Unfortunately, emissions inventory compilation and analysis are not high in the list of funding agencies; the resources and time allocated to these activities are generally not enough to allow in-depth study and the development of more accurate 
techniques and measurements. So we muddle along; diverse groups will continue to develop specific emissions estimates as stepchildren to their main studies. As we so graphically saw in the Marland et al. article [1999] the resulting emissions estimates may be very close when comparing percentages, but can result in large absolute differences, and there is currently no way of identifying which results are more accurate. GEIA has attempted to bring together investigators developing emissions estimates in an attempt to make the whole better than its parts. In this it has been partially successful; some of the inventories developed under the GEIA umbrella have become defacto gold standards in atmospheric chemistry studies. Much more is needed, both in terms of acquiring additional resources and in the revitalization of the cooperative efforts initiated by GEIA.

\section{SUMMARY}

The mathematical modeling of the transport and transformation of trace species in the atmosphere is one of the scientific tools currently used to assess atmospheric chemistry, air quality, and climatic conditions. From the scientific but also from the management perspectives accurate inventories of emissions of the trace species at the appropriate spatial, temporal, and species resolution are required. There are two general methodologies used to estimate regional to global emissions: bottom-up and top-down (also known as inverse modeling). Bottom-up methodologies used to estimate industrial emissions are based on activity data, emission factors (amount of emissions per unit activity), and for some inventories additional parameters (such as sulfur content of fuels). To compile regional and global inventories researchers can either bring together estimates made at the national or sub-national level by national experts or directly estimate emissions based on activity rates from reports compiled by multi-national organizations such as the United Nations and the International Energy agency and on emission factors and other information available in the literature. In all cases the data used must be checked for completeness, transparency, consistency, comparability, and accuracy. These emissions estimates must now be given finer spatial (usually gridded), temporal, and for some inventories species resolution. The location of major stationary sources (power plants, industrial complexes) is usually known, so the emissions can be directly assigned to the appropriate grid cell. For emissions from other activities, such as transportation, spatial resolution is obtained via the use of surrogate information, such as population, land use, traffic counts, etc. which already exists in or can directly be converted to gridded form. To obtain finer temporal resolution (seasonal, daily, weekday/weekend, etc.) auxiliary information such as plant schedules, traffic counts, etc. is used. Speciation factors have been and are being developed to speciate inventories of $\mathrm{NO}_{\mathrm{x}}$ $\left(\mathrm{NO}, \mathrm{NO}_{2}\right)$, particulate matter $\left(\mathrm{PM}_{2.5}, \mathrm{PM}_{10}\right.$; by species), and hydrocarbons (individual species or groups of species).

Top-down (inverse modeling) methodologies directly invert air quality measurements in terms of poorly known but critical parameters to constrain the emissions needed to explain these measurements; values of these parameters are usually computed using atmospheric transport models. Several statistical tools are being used to address the inversion problem, but currently there are several strong limitations to inverse modeling as a tool to estimate emissions. 
Emissions inventory compilation and analysis does not appear to be high on the list of funding agencies. As a result, inventory work is done piecemeal as the stepchild of other projects; duplication of effort can delay advances in the field. The GEIA project of IGAC has attempted to prevent duplication and bring together emissions inventories projects so that the whole is better than its parts. This effort has been partially successful, but much more needs to be done if we are to substantially decrease the uncertainties of emissions data.

\section{REFERENCES}

Arndt, R.L., G.R. Carmichael, D.G. Streets, and N. Bhatti, Sulfur Dioxide Emissions and Sectoral Contributions to Sulfur Deposition in Asia, Atmos. Env., 31, 1553-1572, 1997.

Baker, D.F., An Inversion Method for Determining Time-dependent Surface $\mathrm{CO}_{2}$ Fluxes, in Inverse Methods in Global Biogeochemical Cycles, edited by M.H. P. Kasibhatla, P. Rayner, N. Mahowald, R.G. Prinn, D.E. Hartley, pp. 279-293, American Geophysical Union, Washington DC, 2000.

Baldasano, J.M., and H. Power, Air Pollution Emissions Inventories, in Advances Series in Air Pollution. Chapter 1: Guidelines and Formulation of an Upgrade Source Emissions Model for Atmospheric Pollutants, pp. 238, Computational Mechanics Publications, Southampton, UK, 1998.

Benkovitz, C.M., M.T. Scholtz, J. Pacyna, L. Tarrasón, J. Dignon, E.V. Voldner, P.A. Spiro, J.A. Logan, and T.E. Graedel, Global Gridded Inventories of Anthropogenic Emissions of Sulfur and Nitrogen, J. Geophys. Res., 101 (D22), 29239-29253, 1996.

Bergamaschi, P., R. Hein, C.A.M. Brenninkmeijer, and P.J. Crutzen, Inverse Modeling of the Global CO Cycle. 1. Inversion of CO Mixing Ratios, J. Geophys. Res., 105 (D2), 19091928, 2000a.

Bergamaschi, P., R. Hein, C.A.M. Brenninkmeijer, and P.J. Crutzen, Inverse Modeling of the Global CO Cycle. 2. Inversion of ${ }^{13} \mathrm{C} /{ }^{12} \mathrm{C}$ and ${ }^{18} \mathrm{O} /{ }^{16} \mathrm{O}$ Isotope Ratios, J. Geophys. Res., 105 (D2), 1929-1946, $2000 \mathrm{~b}$.

Berger, J.O., Statistical Decision Theory and Bayesian Analysis, Springer Verlag, New York, NY, 1985.

Bouscaren, R., Inventaire des Emissions de Polluants dans L'Atmosphere dans La Communate Europeenne en 1985, CITEPA, 1990.

Bouscaren, R., CORINAIR 1990, in First Meeting of the Task Force on Emissions Inventories, edited by J.M.P.a.H.D. G. McInnes, Norwegian Institute for Air Research, London, England, 1992.

Bouscaren, R., and J.P. Fontelle, CORINAIR Inventaire des Emissions de Polluants dans L'Atmosphere dans la Communaute Europeenne en 1985. Projet de Rapport Final, Centre Interprofessionnel Technique D'Etudes de la Pollution Atmospherique (CITEPA), Paris, France, 1992.

Bouscaren, R., CORINAIR Technical Annexes Volume 2: Default Emission Factors Handbook, pp. 327, European Commission, Brussels, Belgium, 1995.

Bouscaren, R., and M.-H. Cornaert, CORINAIR Technical Annexes Volumes 1: Nomenclature and Software, pp. 126, European Commission, Brussels, Belgium, 1995. 
Bouscaren, R., J.-P. Fontelle, M.-H. Cornaert, J. Maes, E.d. Roeck, and B. Lübkert, CORINAIR Inventaire des Emissions de Dioxyde de Soufre, D'Oxides D'Azote et de Composés Organiques Volatils dans la Communauté Européenne en 1985, pp. 205, Commission Européenne, Bruxelles, Belgique, 1995.

Byun, D.W., and J.K.S. Ching, Science Algorithms of the EPA Models-3 Community Multiscale Air Quality (CMAQ) Modeling System, Office of Research and Development

U.S Environmental Protection Agency, Research Triangle Park, NC, 1999.

Enting, I.G., Green's Function Methods of Tracer Inversions, in Inverse Methods in Global Biogeochemical Cycles, edited by M.H. P. Kasibhatla, P. Rayner, N. Mahowald, R.G. Prinn, D.E. Hartley, pp. 19-31, American Geophysical Union, Washington, DC, 2000.

Foell, W., M. Amann, G. Carmichael, M. Chadwick, J.P. Hettelingh, L. Hordijk, and Z. Dianwu, RAINS-ASIA: AN ASSESSMENT MODEL FOR AIR POLLUTION IN ASIA, The World Bank, Washington, DC, 1995.

Food and Agriculture Organization of the United Nations, FAOSTAT, Food and Agriculture Organization of the United Nations, 2000.

Franssens, G., D. Fonteyn, M.D. Mazière, and D. Fussen, A Comparison Between Interpolation and Assimilation as Cartography Metods for the SAGE II Aerosol Product, in Inverse Methods in Global Biogeochemical Cycles, edited by M.H. P. Kasibhatla, P. Rayner, N. Mahowald, R.G. Prinn, D.E. Hartley, pp. 155-169, American Geophysical Union, Washington, DC, 2000.

Giering, R., Tangent Linear and Adjoint Biogeochemical Models, in Inverse Methods in Global Biogeochemical Cycles, edited by M.H. P. Kasibhatla, P. Rayner, N. Mahowald, R.G. Prinn, D.E. Hartley, pp. 33-48, American Geophysical Union, Washington, DC, 2000.

Hahn, J., EUROTRAC Data Handbook, pp. 67, EUROTRAC International Scientific Secretariat, Garmisch-Partenkirchen, Germany, 1996.

Heimann, M., and P.S. Kasibhatla, Introduction and Overview, in Inverse Methods in Global Biogeochemical Cycles, edited by M.H. P. Kasibhatla, P. Rayner, N. Mahowald, R.G. Prinn, D.E. Hartley, pp. 1-2, American Geophysical Union, Washington, DC., 2000.

Hein, R., P.J. Crutzen, and M. Heimann, An Inverse Modeling Approach to Investigate the Global Atmospheric Methane Cycle, Global Biogeochemical Cycles, 11, 43-76, 1997.

Høst, G., A Statistical Method for Estimation of European Sulfur Emissions Using EMEP Monitoring Data, pp. 28, Meteorological Synthesizing Centre - West, Norwegian Meteorological Institute, Oslo, Norway, 1996.

Høst, G., and X.K. Dimakos, Estimation of Regional Emissions in Europe Using EMEP Monitoring Data and Some Implications for Network Design, pp. 48, Meteorological Synthesizing Centre - West, Norwegian Meteorological Institute, Oslo, Norway, 1997.

Houghton, J.T., M. Filho, B. Lim, K. Treanton, I. Mamaty, Y. Bonduki, D.J. Griggs, and B.A. Callander, Revised 1996 IPCC Guidelines for National Greenhouse Gas Inventories, Intergovenmental Panel For Climate Change, Paris, France, 1997.

Houweling, S., and H.D. van der Gon, Estimation of Methane Emissions from Rice Fields Using Inverse Modeling, pp. 67-72, National Institute of Public Health and the Environment, Bilthoven, The Netherlands, 1997. 
Houweling, S., T. Kaminski, F. Dentener, J. Lelieveld, and M. Heimann, Inverse Modeling of Methane Sources and Sinks Using the Adjoint of a Global Transport Model, J. Geophys. Res., 104 (D21), 26137-26160, 1999.

Houweling, S., F. Dentener, J. Lelieveld, B. Walter, and E. Dlugokencky, The Modeling of Tropospheric Methane: How Well Can Point Measurements be Reproduced by a Global Model?, J. Geophys. Res., 105 (D7), 8981-9002, 2000.

International Energy Agency, O.f.E.C.a.D., Key World Energy Statistics from the IEA, International Energy Agency, Paris, France, 2000.

International Monetary Fund Staff, World Economic Output: Focus on Transition Economies, International Monetary Fund, Washington, DC, 2000.

Janssen, L.H.J.M., J.G.J. Olivier, and A.R.v. Amstel, Comparison of $\mathrm{CH}_{4}$ Emissions Inventory Data and Emission Estimates from Atmospheric Transport Models and Concentration Measurements, Environ. Sci. and Policy, 2, 295-314, 1999.

Johnson, N.D., M.T. Scholtz, and V. Cassaday, Methods Manual for Estimating Emissions of Common Air Contaminants from Canadian Sources, ORTECH International, Mississauga, Ont., Canada, 1991.

Kaminski, T., M. Heimann, and T. Giering, A Coarse Grid Three-Dimensional Global Inverse Model of the Atmospheric Transport, 2. Inversion of the Transport of $\mathrm{CO}_{2}$ in the 1980s, $J$. Geophys. Res., 104, 18555-18581, 1999a.

Kaminski, T., M. Heimann, and T. Giering, A Coarse Grid Three-Dimensional Global Inverse Model of the Atmospheric Transport, 1. Adjoint Model and Jacobian Matrix, J. Geophys. Res., 104, 18535-18553, 1999b.

Kato, N., and H. Akimoto, Anthropogenic Emissions of $\mathrm{SO}_{2}$ and $\mathrm{NO}_{\mathrm{x}}$ in Asia: Emissions Inventories (plus errata), Atmos. Environ., $26 A$ (16), 2997-3017, 1992.

Lenhart, L., and R. Friedrich, European Emission Data with Hight Temporal and Spatial Resolution, Water, Air \& Soil Pollu., 85, 1897-1902, 1995.

Li, Y.-F., Global Population Distribution Database, United Nations Environment Programme under UNEP Sub-Project FP/1205-95-12, New York, NY, 1996.

Marland, G., R.J. Andres, and T.A. Boden, Global, Regional, and National $\mathrm{CO}_{2}$ Emissions, in Trends 93: a Compedium of Data on Global Change, edited by T.A. Boden, D.P. Kaiser, R.J. Sepanski, and F.W. Stow, pp. 505-584, Carbon Dioxide Information Analysis Center, Oak Ridge, TN, 1994.

Marland, G., A. Brenkert, and J. Olivier, $\mathrm{CO}_{2}$ From Fossil Fuel Burning: A Comparison of ORNL and EDGAR Estimates of National Emissions, Environ. Sci. and Technol., 2 (3), 265-273, 1999.

Moran, A., and J.E. Salt, International Greenhouse Gas Inventory Compilation Systems CORINAIR and IPCC, EU Directorate General XII Environment Programme, 1996.

Motor Vehicle Manufacturers Association of the United States, World Motor Vehicle Data, Motor Vehicle Manufacturers Association of the United States, Detroit, MI, 1998.

Olivier, J.G.J., A.F. Bouwman, J.J.M. Berdowski, C. Veldt, J.P.J. Bloos, A.J.H. Visschedijk, C.W.M.v.d. Maas, and P.Y.J. Zandveld, Sectoral emission inventories of greenhouse gases for 1990 on a per country basis as well as on 1x1 degree, Environ. Sci. and Policy, 2, 241-264, 1999. 
Saeger, M., J. Langstaff, R. Walters, L. Modica, D. Zimmerman, D. Fratt, D. Dulleba, R. Ryan, J. Demmy, W. Tax, D. Sprague, D. Mudgett, and A.S. Werner, The 1985 NAPAP Emissions Inventory (Version 2): Development of the Annual Data and Modelers' Tape, U.S. Environmental Protection Agency, Research Triangle Park, NC, 1989.

Seibert, P., Inverse Modeling of Sulfur Emissions in Europe Based on Trajectories, in Inverse Methods in Global Biogeochemical Cycles, edited by M.H. P. Kasibhatla, P. Rayner, N. Mahowald, R.G. Prinn, D.E. Hartley, pp. 147-154, American Geophysical Union, Washington, DC, 1999.

Shareef, G.S., and L.A. Bravo, Air Emissions Species Manual - Volume I - Volatile Organic Compounds Species Profiles, U.S. Environmental Protection Agency, Research Triangle Park, NC, 1993a.

Shareef, G.S., and L.A. Bravo, Air Emissions Species Manual - Volume II - Particulate Matter (PM)Species Profiles, U.S. Environmental Protection Agency, Research Triangle Park, NC, $1993 b$.

Taguchi, S., Synthesis Inversion of Atmospheric $\mathrm{CO}_{2}$ Using the NIRE Chemical Transport Model, in Inverse Methods in Global Biogeochemical Cycles, edited by M.H. P. Kasibhatla, P. Rayner, N. Mahowald, R.G. Prinn, D.E. Hartley, pp. 239-253, American Geophysical Union, Washington, DC, 2000.

Tarrasón, L., and J. Schaug, Transboundary Acid Deposition in Europe, pp. 246, Norwegian Meteorological Institute, Oslo, Norway, 1999.

The World Bank Group, Global Economic Prospects 2001, pp. 180, The World Bank, Washington, DC, 2000.

U.S. Environmental Protection Agency, Compilation of Air Pollutant Emission Factors, U.S. Environmental Protection Agency, Research Triangle Park, NC, 1985.

U.S. Environmental Protection Agency, Compilation of Air Pollutant Emission Factors (AP-42) Volume 1: Point and Area Sources, U.S. Environmental Protection Agency, Research Triangle Park, NC, 1999.

United Nations, Statistical Yearbook, United Nations, New York, NY, 1988.

United Nations, Energy Statistics, United Nations, New York, NY, 1989.

United Nations Economic Commission for Europe, Procedure for Estimating and Reporting Emission Data Under the Convention on Long-Range Transboundary Air Pollution, United Nations Economic Commission for Europe, Geneva, Switzerland, 1997.

United Nations Framework Convention on Climate Change, UNFCC Guidelines on Reporting and Review, FCCC/CP/1999/7, Conference of the Parties, Bonn, Germany, 2000.

Van Heyst, B.J., M.T. Scholtz, C.M. Benkovitz, A. Mubaraki, J.G.J. Olivier, and J.M. Pacyna, 1990 Global Inventories of $\mathrm{SO}_{\mathrm{x}}$ and $\mathrm{NO}_{\mathrm{x}}$ on a $1^{\circ} \mathrm{X} 1^{\circ}$ Latitude-Longitude Grid, in The Emission Inventory: Regional Strategies for the Future, Air and Waste Management Association, Raleigh, NC, 1999.

Várhelyi, G., Continental and Global Sulfur Budgets - I. Anthropogenic SO2 Emissions, Atmos. Environ., 19, 1029-1040, 1985.

Vermeulen, A.T., R. Eisma, A. Hensen, and J. Slanina, Transport Model Calculations of NWEuropean Methane Emissions, Environ. Sci. and Policy, 2, 315-324, 2000. 
Verstraete, M.M., and B. Pinty, Environmental Information Extraction from Satellite Remote Sensing Data, in Inverse Methods in Global Biogeochemical Cycles, edited by M.H. P. Kasibhatla, P. Rayner, N. Mahowald, R.G. Prinn, D.E. Hartley, pp. 125-137, American Geophysical Union, Washington, DC, 2000.

Wagner, J., R.A. Walters, L.J. Maiocco, and D.R. Neal, Development of the 1980 NAPAP Emissions Inventory, U.S. Environmental Protection Agency, Washington, DC, 1986.

Winguth, A., D. Archer, E. Maier-Reimer, and U. Mikolajewicz, Paleonutrient Data Analysis of the Glacial Atlantic Using an Adjoint Ocean General Circulation Model, in Inverse Methods in Global Biogeochemical Cycles, edited by M.H. P. Kasibhatla, P. Rayner, N. Mahowald, R.G. Prinn, D.E. Hartley, pp. 171-183, American Geophysical Union, Washington, DC, 2000.

World Energy Council, Survey of Energy Resources, World Energy Council, London, UK, 1998.

World Resources Institute, World Resources 2000-2001, pp. 400, World Resources Institute, Washington, DC, 2000. 
Table 1

Canadian Global Interpretation Centre (CGEIC) 1990 Global Inventory of $\mathrm{SO}_{2}$ and $\mathrm{NO}_{\mathrm{x}}$ Emissions from Anthropogenic Sources Sector Description

\begin{tabular}{|c|c|c|}
\hline Main Source & Sector Division & Source Type \\
\hline Power generation & Power generation & Elevated point \\
\hline \multirow[t]{3}{*}{ Fuel use \& combustion } & $\begin{array}{l}\text { Industry (including other } \\
\text { transformation sectors) }\end{array}$ & Low level point \\
\hline & Residential, commercial, other & Area \\
\hline & Incineration & Area \\
\hline \multirow[t]{4}{*}{ Transportation } & Road & Mobile \\
\hline & Non-road (i.e. rail) & Mobile \\
\hline & Air (below $1 \mathrm{~km}$ ) & Mobile \\
\hline & International shipping & Mobile \\
\hline \multirow[t]{5}{*}{ Industrial processes } & $\begin{array}{l}\text { Iron \& steel (excludes coke ovens and } \\
\text { blast furnaces) }\end{array}$ & Elevated point \\
\hline & Non-ferro & Elevated point \\
\hline & Chemicals & Low level point \\
\hline & Pulp \& paper & Elevated point \\
\hline & Other & Low level point \\
\hline Land use & Biomass burning & Area \\
\hline
\end{tabular}

